\title{
ARTHRODIRAN ANATOMY
}

$\mathrm{T}$ THE classification used by E. Stensiö in his recently published Anatomical Studies on the Arthrodiran Head* differs from that in present-day text-books. Stensiö, liko Jarvik, joins the Placodermata with tho Elasmobranchii in a class "Elasmobranchiomorphi". The Placodermata contain the super orders Arthrodira and Holocephali, the former including Gross's Euarthrodira (Arthrodira of Woodward) and the Antiarchi. Stensiö is in agreement with the cogent arguments of Ørvig for relating the Euarthrodiran order of Ptyctodontids with tho modern Chimæras- - "ovorything decidedly goes to prove that the Holocephalans are derived from early primitive Ptyctodontids and consequently in all probability are the last survivors of the Arthrodiran stock". Evidently, many general zoologists and palæontologists will be referring to this work to decide how far these opinions are now to be followed.

The figures and plates of Part 1 are excellently set out and there are many beautiful colour-figures. These, the work of a great authority, writing on his subject, onable a more complete picture of the Euarthrodiran fish to be

* Kungl. Svenska Vetenskapsakademiens Handlingar. Fjarde Serien. Band 9, Nr. 2: Anatomical Studies on the Arthrodiran Head. Part 1: Preface, Geological and Geographical Distribution, the Organization of the Arthro dires, the Anatomy of the Head in the Dolichothoraci, Coccosteomorphi and Pachyosteomorphi. Taxonomic Appendix. By Erik Stensiö. Pp. $419+$ 62 plates. (Stockholm: Almqvist and Wiksell, 1963.) $220 \mathrm{kr}$. formed. But in the reconstructions, based largely on 'serial grindings', comparison is made predominantly with the cranial anatomy of modern Elasmobranchs rather than with that of Acanthodians, Holocephalans, or early Elasmobranchs: this procedure begs the question of whether the Elasmobranchs aro so closely related to the Arthrodires as Stensiö believes. Certainly it is difficult to accept that thoso early fishes were so advanced as they appear here, for example, in the relations of the profundus nerve to the rest of the trigeminal complex.

The systematic arrangement of the orders is based on the author's views on the evolution of the Arthrodiran pectoral fin, although the Dolichothoraci are treated first in the text. Should these views eventually prove to be mistaken, this would detract little from the value of the book. But many special features of the Arthrodires, such as the strange and probably primitive arrangement of the pineal system, and the evolution, apparently, of autostylic jaw-suspensions from a hyostylic one, really need authoritative explanatory diagrams rather than extensive verbal descriptions. Presumably these will be provided in Part 2, which will cover nine orders, including the crucial Ptyctodontids, and a summary. Part 1 lacks a separate index, so on all counts it is to be hoped that Part 2 will appear soon.

\section{H. P. Whrtina}

\section{INSPECTION OF ALKALI, ETC., WORKS}

$\mathrm{T}$ HE one hundredth report on alkali, etc., works in England and Wales for 1963, issued by the Chief Inspector*, covers the centenary year of the Alkali Act. An interesting feature of the report is the brief account appended of the early history of the Act and of the Inspectorate. At the end of the year, 2,061 works were registered under the Act involving operation of 3,331 , but the number of registered works was 16 fewer than at the ond of 1962, and 152 fewer than at the end of 1959 .

The Chief Inspector points out that it is often small works, unsuitably placed and surrounded by dwollinghouses, which take up a disproportionately large amount of the time of the Inspectorate, and neither the number of works nor the schedulod processes registered, nor the national statistics for production, can alone provide a yard-stick for the hazards.

During the year, 10,850 visits were paid, including 135 special visits by the Chiof or Deputy Chief Inspector, of which 244 were to, or in connexion with, works not registered under the Act, 43 being concerned with the control of radioactivo emissions and 43 to, or in connexion with, colliery spoilbanks. During the inspections, 3,433 quantitative analyses were made of gases evolved from the processes, compared with 4,331 in 1962. The decreased number of tests is largely due to the absence of any need for spocial investigations at the older works. In addition, 615 special samples were taken and submitted for analysis by the Government Chemist.

The specific complaints investigated, largely at the roquest of tho local authorities, concern some 323 works,

* Ministry of Housing and Local Government-Scottish Development Department. Alkali, ete. Works Regulation Act, 1906, and Alkali, etc Works Orders, 1928-1963. Alkali, etc. Works Regulation (Scotland) Act 1906 and 1951, and Alkali, etc. Works (Scotland) Orders, 1952 and 1958 One-Frundredth Annual Report on Alkali, etc. Works by tho Chief
1983 . Pp. iv + 84. (London: II.M.S.O., 1864.) 5s. 6d. net.
256 of which were registered under the Act. Complaints against registered works were most numerous against isotope works, ceramic and electricity works, iron and steel works, cement works, and aluminium works, the volume of complaints against the heavy chemical industry being small.

Commenting on the inclusion in the list of noxious or offensive gases under the control of the Inspectorate of compounds which cannot by any manner of means be held to be toxic, the Chief Inspector points out that toxicity is not the full criterion, and that there is the matter of general nuisance and of interference with amenities. The Chief Inspector also points out that the arrangements for visiting the establishments of the Atomic Energy Authority to consider the best practical means for reducing to a minimum the emission of radioactive gases, mists and dusts, and to make sure that any such discharges are regulatod so that public health is in no way in danger, continue to operate adequately. Satisfactory standards continue to be maintained and no public health hazard has arisen. The same satisfactory system is being applied to the nuclear power stations of the Central Electricity Generating Board.

An interesting point noted regarding the cementproduction works is that one of the main factors leading to high dust emission when using estuarine clay is the salt content. Moreover, the main alkali metal in the dust is not sodium but potassium, which seems to be present largely as potassium chloride and can at times be as much as half the emission.

Under the same cover is included the report of the Chiof Inspector of Alkali, etc., Works (Scotland) for the same year. Under the Scottish Act 275 works operating 375 procosses are registered, and some 444 visits were paid, including 44 joint and independent visits by the 
Chief Inspector, of which about 146 visits were on work not falling directly within the provisions of the Act, but within those of other statutes relating to the prevention of air pollution. The experimental programme of testing dust emissions yielded more useful information in the 30 tests made during the year, but it was again apparent that full observance of the recommended procedure for testing was scarcely practical at most works, although close approximations were mado wherever possible. Another markedly defective electrostatic precipitator was found, and again its performance was not suspect by an external instrumental indication of its operation.

To this report also is appended a brief historical account, this time dealing with the operation of the Alkali Act in Scotland during the past hundred years.

\title{
BLAST-FURNACE CEMENT IN SOUTH AFRICA
}

$\mathrm{M}$ ANY years ago it was established (in Germany) that certain slags, by-product of iron-ore smelting in blast-furnaces, if rapidly quenched from the molten state, then finely ground with an activator such as limo or Portland cement, would set and harden very much like ordinary Portland cement. This resulted in the development of a large cement industry in Europe based on waste slag, which, as a result of considerable research over the years, has greatly expanded in production and economic importance, especially in those countries concerned with an indigenous iron and steel industry.

In the case of South Africa there appears to be a basic difference between the available slag from the iron and steel industry compared with that used for cement-making elsowhere, in that the slag produced in the Republic has a much higher magnesia content than that normally used overseas. For some time cement technologists considered that the use of high magnesia slag was liable to lead to disruptive expansion in Portland cement products made from it; consequently this local slag was looked on with suspicion. However, with continuing expansion of the iron and steel industry and concomitant mounting of slag production (this is at present running at $1,200,000$ tons per annum), something drastic had to bo done to counteract the accumulation of this unwanted by-product. Research on the problem was initiated at the National Building Research Institute of the Couneil for Scientific and Industrial Research, Pretoria, and eventually it was demonstrated that this high-magnesia slag was not conducive to unsoundness and that, under prescribed conditions, a good-quality cement could be manufactured from it.

Writing in the South African Review (C.S.I.R., ref. No. R/BOU $108 ; 1963 / 64)$, Dr. N'. Stutterheim, vicepresident of the Council, briefly describes the events leading up to the now successful utilization of this slag. He says: "Discussions between the iron and steel industry, which had sponsored the research, the cement companies and the C.S.I.R, resulted in the manufacture of two types of cement: one an interground mixture of granulated slag and Portland cement clinker and the other a finely ground granulated slag which is then mixed with Portland cement in the concrete mixer on the construction site. . . . Last year about 350,000 tons of granulated slag was converted to cement; i.e., about 12 per cent of the country's cement requirements were met from this source. This is only 30 per cent of slag output whereas at least 80 per cent could be so utilized".

It is concluded that it has now been abundantly proved that it is economic to uso South African slag for cement manufacture; that by so doing capital and running costs are saved; resources of limestone and coal, otherwise required for equivalent Portland cement production, are extended; a cement possessing properties similar to those of Portland cemont, but at lower cost, is being extensively marketed; and it is in the national interest that increasing use be made of this waste slag for cement production.

H. B. Milner

\section{UPTAKE OF HYDROCARBON CARCINOGENS BY LYSOSOMES}

\author{
By DR. A. C. ALLISON and DR. L. MALLUCCl* \\ National Institute for Medical Research, London, N.W.7
}

\begin{abstract}
$\mathrm{A}$ LTHOUGH polybenzenoid hydrocarbon carcinogens have been intensively investigated since their discovery more than thirty years ago, remarkably little is known about their intracellular fate and the way by which they bring out malignant changes. In examining the localization of carcinogens, two main approaches have been used: histological examination of the fluorescence of treated tissues and chemical analysis of isolated coll constituents. The first technique has shown that, both in vivo and in vitro, hydrocarbon carcinogens are quickly taken up into small masses in the cytoplasm of cells and remain demonstrable there for several weeks ${ }^{1-5}$. The second approach has ostablished that if careful fractionations are carried out the careinogens are not found in nuclei or bound to nucleic acid but are present in cytoplasmic constituents, an appreciable proportion being bound to protein ${ }^{6-8}$. Whether hydrocarbon carcinogens become associated with particular cytoplasmic constitu* Holder of a NATO fellowship granted by the Italian National Research
Council.
\end{abstract}

ents has never been clear, and our experiments were undertaken to throw light on this problem.

Cell cultures. Cultures of four cell types were made on coverslips. Primary Macaca monkey kidney cell cultures were grown in Medium 199 (Glaxo) +10 per cent calf serum inactivated by heating at $56^{\circ}$ for $0.5 \mathrm{~h}$. Chick embryo cell cultures were maintained in tris-(hydroxymethyl)-aminomethane-Cey's medium with peptone and lactalbumin hydrolysate ${ }^{\circ}$. HoLa cells were cultured in Medium $199+5$ per cent inactivated calf serum. Macrophages were obtained without prior stimulation by intraporitoneal inoculation of $3 \mathrm{ml}$. of culture medium containing $10 \mathrm{r} . \mathrm{U}$. of heparin per $\mathrm{ml}$. into mice of strain $V S B S / N I M R$ weighing 18-20 g. After brief massage the cells were gathered, washed and dispensed in tubes containing small coverslips. The culture medium was solution $199+20$ per cent inactivated calf serum.

Carcinogens. Hydrocarbon carcinogens (9,10-dimethyl1:2-benzanthracene (DMBA) : 20-methylcholanthrene (MCA); $1: 2,5: 6$-dibenzanthracene (DBA); and $3: 4$ - 